\title{
Black Students in U.S. Higher Education: Toward Improved Access, Adjustment, and Achievement
}

\begin{abstract}
Walter R. Allen
This paper seeks to broaden our knowledge and understanding of black student experiences in U.S. higher education over the past 20 years. Toward this end, I analyze black student enrollment/earned degree trends in the state of Michigan during the 1965-80 period; examine the institutional experiences of black students who enrolled as freshmen at the University of Michigan between 1975 and 1983; and assess the correlates of access, adjustment, and achievement of 700 black college students who attended six predominantly white public institutions in 1981. The analyses cut across four different levels of U.S. higher education (national, state, institutional, and individual) and shed considerable light not only on black student experiences but also those of other minority and white students as well. Based on the result of the multidimensional analyses, I set forth an agenda for action to improve the status of blacks in higher education.
\end{abstract}

The decade of the 1960s marked a watershed in American history, when, in response to the civil rights movement, our society made major efforts to address some of the wrongs imposed on its black citizens for centuries. Increasing black access to higher education was seen as a major solution to the problem of racial inequality, and the decade witnessed the beginning of a dramatic increase in the enrollment of black students in predominantly white colleges and universities. This response by institutions of higher learning to the civil rights movement was abetted by unusually favorable conditions within higher education: public support for higher education was high, and colleges and universities were experiencing a period of continual expansion.

Today, 20 years later, both the mood of the country on racial issues and the state of higher education have changed. The national moral response to black demands for equality has been tempered by ambivalence and the persistent problems associated with a downturn in the U.S. economy. Higher education generally has moved from a period of boundless expansion and optimism to one of retrenchment and financial constraint. This has been reflected in a dilution of higher education's commitments to blacks and other minorities. The enrollment of black students in four-year, predominantly white institutions has fallen short of anticipated goals and is, in fact, declining. Black faculty and administrators

Walter R. Allen, Department of Sociology, University of Michigan, Ann Arbor, MI 48109. 
have remained a minute proportion of the tenured and senior staff in white colleges and universities. And studies of black students suggest that many of them have negative, anomic experiences in white institutions, suffering lower achievement and higher attrition (Thomas, 1981).

Higher education's complacency on these issues has been shaken in recent months by the outbreak of ugly racial incidents on a number of college campuses across the U.S. (see paper by Farrell and Jones in this issue). This has led to considerable self-examination in many colleges and universities and, in some cases, a revitalization of the commitment to black and minority students. But the question of how to implement this commitment is by no means clear. Despite a generation of experience with a significant presence of black students in white institutions of higher education, we have only a limited and imprecise understanding of the factors that affect the increases and decreases in an institution's enrollment of minority students, and once enrolled, of the factors that provide these students an institutional and educational experience that is personally gratifying and academically successful (Allen, 1987). Thus, even when an institution is ready to commit more resources to the minority endeavor, the institution's leaders lack clear directions on how best to expend these resources, largely because the opening of U.S. higher education to black and minority students has been the subject of very little systematic, quantitative, and/or analytic research.

In this paper I attempt to broaden our knowledge and understanding of black student experiences in U.S. higher education over the past 20 years. To achieve this goal, I (1) analyze black student enrollment/earned degree trends in the state of Michigan during the 1965-80 period; (2) examine the institutional experiences of black students who enrolled as freshman at the University of Michigan between 1975 and 1983; and (3) assess the correlates of access, adjustment, and achievement of 700 black college students who attended six predominately white public institutions in 1981. Much of what is revealed by the analyses reported on here, which cut across four different levels of the U.S. higher educational system (national, state, institutional, and individual), sheds considerable light not only on black student experiences but also on those of other minority and white students as well. Based on the findings, I set forth in the discussion section an agenda for action to improve the status of blacks in higher education.

\section{BLACK STUDENT ENROLLMENT/EARNED DEGREE TRENDS IN MICHIGAN}

\section{Undergraduate Enroliment Patterns}

\section{Public Colleges and Universities}

Publicly supported state universities and colleges enroll the majority of black students in U.S. higher education. Generally speaking, these schools tend to be 
larger in size and cheaper to attend and tend to have greater academic program diversity and less rigorous admissions requirements than is true for privately controlled institutions of higher education. Thus, black college students in the U.S. are more likely to attend state-supported or public institutions than they are to attend private institutions. The same pattern holds true for the state of Michigan, so we begin with a consideration of black student college enrollment and earned degree patterns for state-controlled institutions in Michigan.

In 1970, the 7,586 black students enrolled in Michigan's public universities were $5.3 \%$ of the total student enrollment. Asian, Hispanic, and American Indian students together totaled 1,784 students, with each group accounting for less than $.5 \%$ of the total student enrollment. Of all students in Michigan's public universities and colleges, $93 \%$ were white. By 1976, there were 15,521 black students on the public campuses of the state of Michigan-twice the number in 1970 -representing $9.4 \%$ of total enrollment. White students were $86 \%$ of the total enrollment, and American Indians, Asians, and Hispanics were, respectively, $.5 \%, .6 \%, .8 \%$ of total enrollment. As of 1986 , the absolute number of black students in Michigan public institutions had grown to 16,550, although their percentage of total student enrollment had declined to $7 \%$. The Asian (1.8\%) and Hispanic (1.2\%) fractions had also grown, while the American Indian (.5\%) and white student $(85.2 \%)$ fractions had remained basically stable.

Five campuses have historically enrolled the majority of black students in Michigan public higher education. In fall 1986, the five largest enrollments of black students in Michigan colleges were at Wayne State University $(6,288)$, Michigan State University (2,518), University of Michigan-Ann Arbor (1,710), Eastern Michigan University $(1,665)$, and Western Michigan University $(1,165)$. Together these schools accounted for $81 \%$ of the total 1986 black Michigan public college enrollment.

Wayne State University's enrollment alone represented $38 \%$ of the total black student enrollment in 1986. Since 1970, black enrollment has tripled at Eastern Michigan University and roughly doubled on the other campuses. The Asian student population has grown by 10 times at the University of Michigan and by 5 times at Wayne State since 1970. Similarly, since 1970 the white student enrollment on these campuses has grown between a half and a third.

In summary, blacks student enrollment in Michigan's four-year public university undergraduate programs increased rapidly from $5 \%$ of total enrollment in 1970 to a peak of $11 \%$ in 1976 , declining steadily since then to the 1986 level of $7 \%$. In absolute terms, the number of black students attending these universities and colleges doubled. Despite clear and dramatic progress during this period, the recent decline in black enrollment and trends on specific campuses have dampened the black community's optimism about black progress in Michigan higher education.

\section{Private Colleges and Universities}

One-third of black college and university students attend independent 
institutions in Michigan. In 1970, black students represented $4.9 \%$ of the total student enrollment on private campuses; white students were $94 \%$ of the total; Asians, .5\%; American Indians, .2\%; and Hispanics, .7\%. In 1970, the proportion of racial and ethnic students enrolled in private institutions of higher education in Michigan was roughly equal to their proportion in public institutions. In 1976, blacks were $10 \%$ of the private school enrollment and whites were $82 \%$ of the total, roughly equalling their proportions on public campuses. The proportions of Asians and Hispanics on private campuses was twice their proportion on public campuses. By 1986, the black ratio had declined such that blacks were $10 \%$ of private campus enrollment, compared to $7 \%$ on public campuses, while the white ratio remained basically unchanged.

Predictably, four of the five independent Michigan colleges and universities with the highest black student enrollment are located in Detroit, where the majority of the state's black population is concentrated. The five private institutions with the highest black enrollment in 1986 were University of Detroit (1,008), Marygrove College (883), Mercy College (822), Andrews University (471), and Madonna College (320). Together these schools account for $45 \%$ of the black student enrollment in Michigan's independent colleges and universities. The long-term pattern for these colleges, unlike that at many public schools, has produced steady growth in black student enrollment since 1970. It is striking to note that the private colleges' percentage of Michigan's total black student college enrollment grew from $18 \%$ in 1970 to $32 \%$ in 1986 . It is clear that the private share of black college enrollments in Michigan has been increasing, as the public share has decreased. The increase in private school enrollment has not been sufficient, however, to offset the dramatic decrease in public school enrollment.

In summary, the overall proportion of black students in independent institutions of higher education in Michigan doubled from 1970 to 1986 . Unlike public institutions, private institutions have not shown swift, sharp declines in black student enrollment.

\section{Two-Year Public Colleges}

National patterns reveal black Americans to be disproportionately represented among students who attend two-year junior or community colleges. Many students in two-year public colleges do not actually complete the requirements for an Associate of Arts (A.A.) degree. The instances where these students transfer into four-year degree programs are also rare, since the articulation between two- and four-year institutions is limited (see paper by Orfield in this issue). Thus, students enrolled in two-year public colleges experience some disadvantage relative to their peers on four-year campuses. They are generally weaker academically, come from poorer economic backgrounds, and tend not to earn degrees beyond the high school diploma. It is therefore significant that such a larger number of black students enrolled in higher education attend two-year colleges. 
From 1976 to 1984 , the number of students enrolled in Michigan two-year public colleges grew by 52,363 , or $38 \%$. In 1976 , black students were $14 \%$ of total enrollment at two-year public colleges; by 1984 , black students were $11 \%$ of the total. For both years, black students' proportion of total enrollment on two-year public campuses exceeded their proportion of enrollment on four-year public campuses by over 3 percentage points. Through whatever combination of circumstances, Michigan black students in higher education are much more likely to attend two-year institutions. By comparison, Asian, Hispanic, and white students are equally as likely to attend four-year colleges as they are to attend two-year colleges.

\section{Graduate Enrollment Pattern}

The discussion of black graduate enrollment will be confined to public institutions, since the overwhelming majority of the state's black graduate students are enrolled on state-controlled campuses. In 1976, the number of students in graduate education on public campuses was 46,261 . By 1985 , this number had declined to 37,140 , a reduction of $20 \%$. Over the same period, the black graduate student population dropped from $7 \%(3,178)$ to $5 \%(1,881)$ of the total enrollment. In 1985, the campuses with the largest black graduate student enrollment were Wayne State University (826), University of Michigan-Ann Arbor (375), Michigan State University (289), and Eastern Michigan University (153). Figure 1 provides a dramatic illustration of the serious declines that have occurred in black graduate enrollment. Between 1976 and 1985, black graduate student enrollment at the University of Michigan, Michigan State, and Eastern Michigan dropped by more than half.

The future implications of such dramatic declines in the number of black graduate students are staggering. Currently, the shortage of black advanced degree holders is nearing crisis dimensions, as universities, government, and the

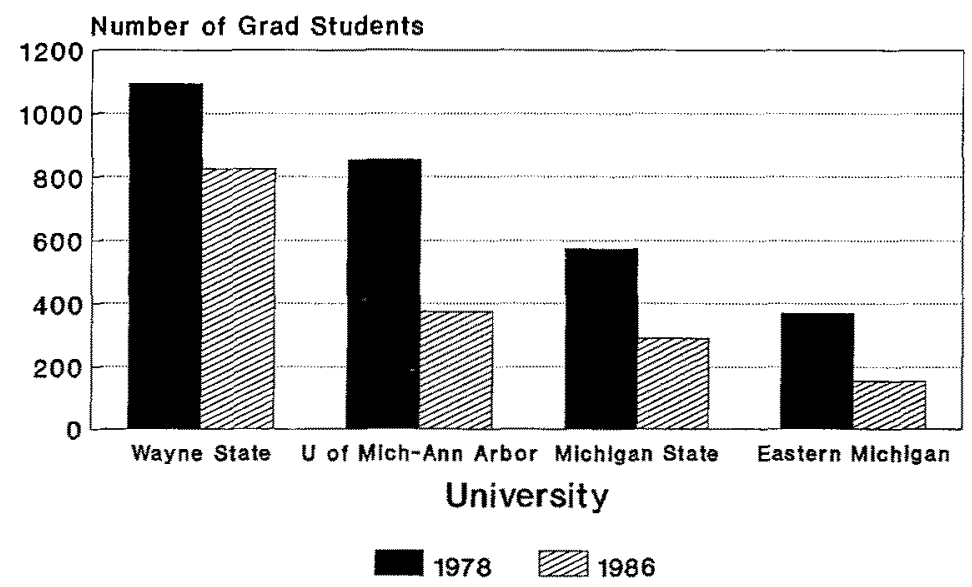

FIG. 1. Black graduate student enrollment in state universities in Michigan in 1978 and 1986. 
corporate world compete for a shrinking pool of eligible graduates. The sparse number of black students presently enrolled in graduate education signals that the problem will worsen dramatically in the near future. Even if enrollments were sizably expanded immediately, there would still be a 3- to 7-year lag period before those new entrants were finished with their degrees and available to enter the labor force.

\section{Black Earned Degrees}

The final area of statistical comparison for this study of blacks in Michigan higher education is earned degrees: bachelor's, master's, doctor's, first professional, and associate degrees awarded by Michigan colleges and universities, both public and private, in 1976 and 1986 (Tables 1 and 2). Comparing 1976 to 1986 , the number of bachelor's degrees awarded by Michigan institutions was roughly equivalent $(37,026$ to 38,132$)$, while the number of master's degrees dropped substantially $(16,005$ to 11,804$)$, and the number of doctorates also decreased $(1,498$ to 1,259$)$. On the other hand, there was an increase from 1976 to 1986 in the number of first professional degrees awarded $(2,354$ to 2,722$)$, and a sizable increase in associate degrees $(20,535$ to 27,866).

Degrees earned by black students declined in every category from 1976 to 1986, except for associate degrees, where earned degrees increased by 140 . This increase was not sufficient to offset declines of 458 bachelor's degrees, 438 master's degrees, 58 doctor's degrees, and 227 first professional degrees. In short, blacks earned a total of 1,041 fewer degrees from Michigan colleges and universities in 1986 than in 1976. For the same 10-year period, Asians roughly doubled their number of degrees earned in each degree category, and whites were also successful over the period in increasing their number of earned degrees. The fact that the decline in the number of degrees awarded to blacks was across the board refutes explanations that attribute declines in master's degrees and doctorates awarded blacks to shifting interests. The across-theboard pattern challenges the argument that a sizable proportion of black students who would have earned graduate degrees earlier now choose instead to earn professional degrees.

\section{INSTITUTIONAL EXPERIENCES OF BLACK STUDENTS AT THE UNIVERSITY OF MICHIGAN}

The analyses reported on in this section are based on the records of students matriculating between 1975 and 1981 at the University of Michigan. Since 1975 the registrar's office has compiled (and updated annually through students' departure from the institution) information on entering freshmen classes. Among the items compiled are student demographic characteristics, grades, academic progress, entrance examination scores, and field of study. The dataset on which the analyses that follow are based included 30,806 students of which 
TABLE 1.

Earned Degrees, by Race, Ethnicity, and Gender-Michigan Colleges and Universities, 1976

\begin{tabular}{|c|c|c|c|c|c|c|c|}
\hline \multirow[b]{2}{*}{ Degree } & \multicolumn{2}{|c|}{$\begin{array}{l}\text { American } \\
\text { Indian } \\
\text { Alaskan } \\
\text { Native }\end{array}$} & \multicolumn{2}{|l|}{$\begin{array}{c}\text { Black } \\
\text { Non- } \\
\text { Hispanic } \\
\end{array}$} & $\begin{array}{l}\text { Asian or } \\
\text { Pacific } \\
\text { Islander }\end{array}$ & \multicolumn{2}{|c|}{ Hispanic } \\
\hline & Number & $\%$ & Number & $\%$ & Number & Numbe & $\%$ \\
\hline Bachelor's Degree $(51)^{\mathrm{a}}$ & 81 & .2 & 2,420 & 6.5 & 204 & 289 & .8 \\
\hline Female & 32 & .2 & 1,382 & 8.5 & 86 & 122 & .8 \\
\hline Male & 49 & .2 & 1,038 & 5.0 & 118 & 167 & .8 \\
\hline Master's Degree (21) & 24 & .1 & 1,217 & 7.6 & 117 & 141 &. \\
\hline Female & 13 & .2 & 806 & 1.3 & 47 & 61 & .9 \\
\hline Male & 11 & .1 & 411 & 4.6 & 70 & 80 & .9 \\
\hline Doctor's Degree (7) & 3 & .2 & 132 & 8.8 & 20 & 28 & 1.9 \\
\hline Female & 2 & .5 & 46 & 2.2 & 2 & 5 & 1.3 \\
\hline Male & 1 & .1 & 86 & 7.7 & 18 & 23 & 2.1 \\
\hline \multicolumn{8}{|l|}{ First Professional } \\
\hline Degree $(10)$ & 1 & .0 & 343 & 4.6 & 10 & 37 & 1.6 \\
\hline Female & 0 & .0 & 52 & 3.8 & 2 & 2 & \\
\hline Male & 1 & .1 & 291 & 4.7 & 8 & 35 & 1.8 \\
\hline Associate's Degree (68) & 31 & .2 & 2,269 & 1.0 & 74 & 196 & 1.0 \\
\hline Female & 13 & .1 & 1,274 & 2.9 & 30 & 79 & .8 \\
\hline \multirow[t]{3}{*}{ Male } & 18 & .2 & 995 & 9.4 & 44 & 117 & 1.1 \\
\hline & \multicolumn{2}{|c|}{$\begin{array}{c}\text { Total } \\
\text { Minority }\end{array}$} & \multicolumn{2}{|c|}{$\begin{array}{c}\text { White } \\
\text { Non- } \\
\text { Hispanic }\end{array}$} & \multicolumn{2}{|c|}{$\begin{array}{l}\text { Non- } \\
\text { resident } \\
\text { Alien }\end{array}$} & \multirow[b]{2}{*}{ Total } \\
\hline & Number & $\%$ & Number & $\%$ & Number & $\%$ & \\
\hline Bachelor's Degree $(51)^{\mathrm{a}}$ & 2,994 & 8.1 & 33,365 & 90.1 & 667 & 1.8 & 37,026 \\
\hline Female & 1,662 & 10.0 & 14,447 & 88.9 & 190 & 1.2 & 16,259 \\
\hline Male & 1,372 & 6.6 & 18,918 & 91.1 & 477 & 2.3 & 20,767 \\
\hline Master's Degree (21) & 1,499 & 9.4 & 13,394 & 83.7 & 1,112 & 6.9 & 16,005 \\
\hline Female & 927 & 13.0 & 5,908 & 82.9 & 295 & 4.1 & 7,130 \\
\hline Male & 572 & 6.4 & 7,486 & 84.3 & 817 & 9.2 & 8,875 \\
\hline Doctor's Degree (7) & 183 & 12.2 & 1,132 & 75.6 & 183 & 12.2 & 1,498 \\
\hline Female & 55 & 14.6 & 292 & 77.2 & 31 & 8.2 & 378 \\
\hline Male & 128 & 11.4 & 840 & 75.0 & 152 & 13.6 & 1,120 \\
\hline \multicolumn{8}{|l|}{ First Professional } \\
\hline Degree (10) & 391 & 16.6 & 1,912 & 81.2 & 51 & 2.2 & 2,354 \\
\hline Female & 56 & 14.8 & 309 & 81.7 & 13 & 3.4 & 378 \\
\hline Male & 335 & 17.0 & 603 & 81.1 & 38 & 1.9 & 1,976 \\
\hline Associate's Degree (68) & 2,570 & 12.5 & 17,809 & 86.7 & 156 & .8 & 20,535 \\
\hline Female & 1,396 & 14.1 & 8,478 & 85.6 & 27 & .3 & 9,901 \\
\hline Male & 1,174 & 11.0 & 9,331 & 87.7 & 129 & 1.2 & 10,634 \\
\hline
\end{tabular}

${ }^{a}$ Number of institutions reporting.

Source: DHEW Earned Degrees Data, National Center for Education Statistics, 1976. 
TABLE 2.

Earned Degrees, by Race, Ethnicity, and Gender-Michigan Colleges and Universities, 1986

\begin{tabular}{|c|c|c|c|c|c|c|c|}
\hline \multirow[b]{2}{*}{ Degree } & \multicolumn{2}{|c|}{$\begin{array}{c}\text { American } \\
\text { Indian } \\
\text { Alaskan } \\
\text { Native }\end{array}$} & $\begin{array}{c}\text { Black } \\
\text { Non- } \\
\text { Hispanic }\end{array}$ & \multicolumn{2}{|c|}{$\begin{array}{c}\text { Asian or } \\
\text { Pacific } \\
\text { Islander }\end{array}$} & \multicolumn{2}{|c|}{ Hispanic } \\
\hline & Number & $\%$ & Number & $\mathrm{Nu}$ & per & Numbe & $\%$ \\
\hline Bachelor's Degree $(52)^{a}$ & 121 & .3 & 1962 & & 1.1 & 306 & .8 \\
\hline Female & 63 & .3 & 1270 & & .9 & 164 & .9 \\
\hline Male & 58 & .3 & 692 & & 1.3 & 142 & .7 \\
\hline Master's Degree (29) & 44 & .4 & 779 & & 2.0 & 131 & 1.1 \\
\hline Female & 20 & .4 & 489 & & 1.6 & 73 & 1.1 \\
\hline Male & 24 & .4 & 290 & & 2.4 & 58 & .9 \\
\hline Doctor's Degree (10) & 2 & .2 & 74 & & 2.4 & 20 & 1.6 \\
\hline Female & 1 & .3 & 36 & & 2.5 & 6 & 1.5 \\
\hline Male & 1 & .1 & 38 & & 2.3 & 14 & 1.6 \\
\hline \multicolumn{8}{|l|}{ First Professional } \\
\hline Degree (12) & 6 & .2 & 116 & & 1.0 & 34 & 1.2 \\
\hline Female & 4 & .5 & 44 & & 1.2 & 6 & .7 \\
\hline Male & 2 & .1 & 72 & & .9 & 28 & 1.5 \\
\hline Associate's Degree (67) & 149 & .5 & 2409 & & .7 & 303 & 1.1 \\
\hline Female & 90 & .5 & 1578 & & .4 & 177 & 1.1 \\
\hline \multirow[t]{3}{*}{ Male } & 59 & .5 & 831 & & 1.0 & 126 & 1.1 \\
\hline & \multicolumn{2}{|c|}{$\begin{array}{c}\text { Total } \\
\text { Minority }\end{array}$} & \multicolumn{2}{|c|}{$\begin{array}{c}\text { White } \\
\text { Non- } \\
\text { Hispanic }\end{array}$} & \multicolumn{2}{|c|}{$\begin{array}{c}\text { Non- } \\
\text { resident } \\
\text { Alien }\end{array}$} & \\
\hline & Number & $\%$ & Number & $\%$ & Number & $\%$ & Total \\
\hline Bachelor's Degree $(52)^{a}$ & 2,820 & 7.4 & 33,941 & 89 & 1,227 & 3.2 & 38,132 \\
\hline Female & 1,673 & 8.9 & 16,711 & 88.8 & 361 & 1.9 & 18,825 \\
\hline Male & 1,147 & 5.9 & 17,230 & 89.2 & 866 & 4.5 & 19,307 \\
\hline Master's Degree (29) & 1,190 & 10.1 & 8,908 & 75.5 & 1,587 & 13.4 & 11,804 \\
\hline Female & 671 & 12.1 & 4,468 & 80.3 & 372 & 6.7 & 5,567 \\
\hline Male & 519 & 8.3 & 4,440 & 71.2 & 1,215 & 19.5 & 6,237 \\
\hline Doctor's Degree (10) & 126 & 10.0 & 876 & 69.9 & 257 & 20.4 & 1,259 \\
\hline Female & 53 & 13.4 & 301 & 76.2 & 41 & 10.4 & 395 \\
\hline Male & 73 & 8.4 & 575 & 66.6 & 216 & 25.0 & 864 \\
\hline \multicolumn{8}{|l|}{ First Professional } \\
\hline Degree (12) & 182 & 6.7 & 1,726 & 63.4 & 39 & 1.4 & 2,722 \\
\hline Female & 64 & 7.5 & 553 & 65.0 & 6 & .7 & 851 \\
\hline Male & 118 & 6.3 & 1,173 & 62.7 & 33 & 1.8 & 1,871 \\
\hline Associate's Degree (67) & 3,044 & 10.9 & 23,669 & 84.9 & 270 & 1.0 & 27,866 \\
\hline Female & 1,915 & 11.7 & 13,898 & 84.7 & 101 & .6 & 16,412 \\
\hline Male & 11,129 & 9.9 & 9,771 & 85.3 & 169 & 1.5 & 11,454 \\
\hline
\end{tabular}

a Number of institutions reporting.

Source: Postsecondary information Unit, Michigan Department of Education, 1986. 
12,066 were currently enrolled in the university. For currently enrolled students, the academic record analyzed is the student's transcript file though fall 1982. For the remaining 18,740 students, who were no longer enrolled, the academic records analyzed include data and information up to the student's final term of enrollment. In $60 \%$ of these cases $(11,163)$ the final term of enrollment corresponds to term of graduation. For the remaining $40 \%(7,577)$, this final term represents the term in which their University of Michigan careers ended for reasons other than graduation (e.g., dropout or transfer).

Results of descriptive analyses of these data are generally illustrative of characteristics of students who attend this university. The results therefore may be cautiously generalized to the category of predominantly white, large, midwestern, prestigious, state-supported universities. Thirty-six percent of freshman who entered school in 1975 successfully completed degree requirements $(11,163)$. One-quarter of the cohort left school without their degrees (7,577) after 6 years (1975-1981). The remaining 39\% were currently enrolled $(12,066)$ as of fall 1981 . The overwhelming majority of students were white, with 1,738 black $(5.7 \%), 116$ American Indian $(.4 \%), 860$ Asian $(2.8 \%)$, and 358 Hispanic (1.2\%) students. Males were slightly more numerous than females $(55 \%$ versus $45 \%)$.

Predictably, bivariate analyses showed that students with better grades in high school, better Scholastic Aptitude Test (SAT) scores, and better grades in college were more likely to graduate. Graduates have average high school grades of 3.56 , compared to 3.32 for dropouts; combined verbal and quantitative SAT scores of 856 , compared to 839 for dropouts; and average college grades of 3.68 , compared to 2.37 for dropouts.

Comparisons of racial/ethnic groups in the total dataset revealed important differences. Asian and white student dropout rates (21\% and $23 \%$, respectively) were much lower than those of American Indians, blacks, and Hispanics (38\%, $38 \%$, and $39 \%$ respectively). For whites, this advantage translates into a higher percentage graduating (37\%), as compared with American Indians (20\%), blacks (30\%), Hispanics (30\%), and Asians (28\%). The percentage of Asian graduates is somewhat distorted, since due to their relatively recent entry into the university, over half were currently enrolled-as compared to less than $40 \%$ of the other groups. Based on other measures, the proportion of Asians who graduate can be expected eventually to equal or exceed that of whites (see paper by Wang in this issue).

Comparisons of high school grades, SAT scores, and grades in college presage some of the findings just described. Asians and whites had the highest mean high school grades (3.61 and 3.50), followed by Hispanics (3.18), American Indians (3.16), and blacks (2.91). Mean verbal SAT scores were highest for whites (514), followed by Asians (498), American Indians (465), Hispanics (459), and blacks (419). Mean quantitative SAT scores were highest for Asians (578), followed by whites (550), American Indians (513), Hispanics, (506) and blacks (447). College grade differences were even more significant: 
mean grades were highest for whites and Asians ( 3.24 and 3.22, respectively), followed by American Indians, Hispanics, and blacks $(2.75,2.65$, and 2.24, respectively).

Students' final programs of enrollment also revealed clear differences by race and ethnicity. Comparisons of students' major field distributions and their proportional representation in the student body revealed that although black students represented only $5.7 \%$ of the total enrollment, they were $14 \%$ of Education majors, $20 \%$ of majors in the Arts and Sciences College, $7 \%$ of Nursing majors, and $10 \%$ of Pharmacy majors. Black students were proportionally underrepresented in Engineering (3.7\%), Medicine $(4.9 \%)$, Architecture (4.3\%), Business Administration (4.7\%), and Art (2.1\%). Asian students, who comprised $2.8 \%$ of student enrollment, were overrepresented in Medicine (12.4\%), Architecture (5\%) and Pharmacy (4.5\%). Asian students were underrepresented in Business Administration (1.9\%), Education (.6\%), Nursing (.9\%), and Art (1.7\%). On the other hand, white students were overrepresented, relative to their $90 \%$ of total enrollment in Art (95\%), Dental Hygiene (98\%), and Resource Management (96\%).

Internal comparisons between students who dropped out, those who graduated, and those currently enrolled clarified many of the findings just reported. Black students are disproportionate among students who leave school for reasons other than graduation. More important, however, is the fact that black students were twice as likely to drop out $(45 \%)$ for academic reasons than were white (25\%) and Asian (26\%) students. Analysis of the group of students no longer enrolled reveals that black, Native American, and Hispanic students were considerably less likely than Asian and white students to complete their programs of study successfully (respective percentages for completion are 44 , 38,57 , and 61 ).

When graduating students are divided into categories of those who finish (1) early, (2) on time, (3) the summer after scheduled graduation, and (4) later than the summer after scheduled graduation, further information is provided on important racial/ethnic differences (Table 3). Twenty-nine percent of black and Hispanic students graduated late (i.e., during the fifth year of enrollment), as compared to $20 \%$ of Asians and whites. Rates of on-time graduation were as follows: Asians, $54 \%$ and whites, $65 \%$. As expected, rates of on-time graduation increased in direct proportion to increases in high school grades, rank in high school graduating class, SAT scores, and college grades.

Within racial and ethnic categories, black females were more likely than black males to graduate on time $-67 \%$ versus $33 \%$. Significantly, no substantial sex differences were found for the other racial/ethnic groups. Combined SAT scores effectively differentiated early from on-time graduates across groups. Mean combined SAT scores for early, on-time, and late graduates by race provide a basis for comparison: blacks $-920,860$, and 860; Asians-1197, 1120, and 1010; American Indians-1230, 970, and 800; Hispanics-1120, 
TABLE 3.

Cumulative Percentage of Black, Hispanic, Asian, and White Undergraduates Obtaining Baccalaureate Degrees Four, Five, and Six Years after Initial Enrollment ${ }^{a}$

\begin{tabular}{|c|c|c|c|c|}
\hline Entering Fir & ar Cohort & $\begin{array}{l}\text { 75-Fall } 19 \\
\text { nn Arbor }\end{array}$ & e Univer & Aichigan, \\
\hline & & Cur & $\%$ Gradu & fter \\
\hline Enrollment & & 4 Years & 5 Years & 6 Years \\
\hline Fall 1975 & Black & 29.4 & 39.2 & 45.5 \\
\hline & Hispanic & 28.8 & 38.5 & 44.2 \\
\hline & Asian & 52.5 & 52.6 & 61.5 \\
\hline & White & 51.4 & 59.3 & 65.0 \\
\hline Fall 1976 & Black & 30.2 & 43.8 & 50.0 \\
\hline & Hispanic & 31.6 & 52.6 & 54.4 \\
\hline & Asian & 53.1 & 67.2 & 72.3 \\
\hline & White & 47.1 & 65.5 & 70.7 \\
\hline Fall 1977 & Black & 27.8 & 47.2 & 50.9 \\
\hline & Hispanic & 42.8 & 55.1 & 57.1 \\
\hline & Asian & 40.2 & 61.6 & 69.0 \\
\hline & White & 50.8 & 68.1 & 71.7 \\
\hline Fall 1978 & Black & 37.4 & 55.2 & 55.7 \\
\hline & Hispanic & 37.7 & 52.8 & 59.6 \\
\hline & Asian & 52.0 & 79.0 & 80.0 \\
\hline & White & 53.2 & 71.1 & 72.9 \\
\hline Fall 1979 & Black & 35.0 & 49.8 & 58.6 \\
\hline & Hispanic & 36.6 & 42.9 & 50.0 \\
\hline & Asian & 43.8 & 63.2 & 69.1 \\
\hline & White & 55.0 & 71.1 & 76.0 \\
\hline Fall 1980 & Black & 36.8 & 56.6 & 59.9 \\
\hline & Hispanic & 31.3 & 48.9 & 52.1 \\
\hline & Asian & 58.0 & 71.3 & 78.3 \\
\hline & White & 54.2 & 72.1 & 75.4 \\
\hline Fall 1981 & Black & 26.6 & 43.9 & 47.1 \\
\hline & Hispanic & 52.9 & 70.6 & 78.4 \\
\hline & Asian & 61.1 & 77.8 & 79.2 \\
\hline & White & 57.3 & 75.9 & 78.5 \\
\hline Fall 1982 & Black & 32.4 & 55.3 & \\
\hline & Hispanic & 43.5 & 56.6 & \\
\hline & Asian & 60.9 & 78.4 & \\
\hline & White & 59.0 & 76.5 & \\
\hline Fall 1983 & Black & 29.1 & & \\
\hline & Hispanic & 50.0 & & \\
\hline & Asian & 54.5 & & \\
\hline & White & 58.3 & & \\
\hline
\end{tabular}

${ }^{a}$ U.S. citizens and permanent resident aliens in degree credit programs. 
940, and 960; and whites $-1170,1090$, and 1080. For Asians and American Indians, combined SAT scores also clearly differentiated on-time from late graduates.

Comparisons within the group of currently enrolled students illustrate students' degree progress. Are students ahead of schedule, making normal progress, or behind schedule, as measured by credit hours earned per term of enrollment? Consistent with the preceding patterns, black students were overrepresented in the category of students behind schedule, that is, students who had fewer cumulative credit hours than the norm for their year in school. Fewer than half the black students $(44 \%)$ were on schedule, as compared with $75 \%$ of whites, $73 \%$ of Asians, $65 \%$ of Hispanics, and $51 \%$ of American Indians. Students making normal degree progress were clearly differentiated from those behind schedule in terms of high school grade point average, combined SAT scores, and college grades. Comparisons across racial/ethnic group revealed clear differences between late and on-schedule students in combined SAT scores: blacks, 899 vs. 873; Asians, 1110 vs. 1050; American Indians 1000 vs. 960 ; Hispanics, 1000 vs. 920 ; and whites, 1095 vs. 1073 . In a now familiar pattern, black students' combined SAT scores-in the range of the 800 s - were the lowest of the five racial/ethnic groups, whereas Asian students' scores - in the range of the $1100 \mathrm{~s}$ - were the highest.

A longitudinal analysis of the academic careers of the 18,740 dropouts was conducted. Over $50 \%$ of Asians and whites stayed in college through graduation, and less than 50\% of blacks, American Indians, and Hispanics persisted in college through completion. Compared to the total population, black students were nearly three times as likely to leave college for academic reasons (29\% vs. $11 \%$ ). The proportion of dropouts for academic reasons among Hispanics and American Indians was roughly twice the proportion in the total student population.

Tracing student careers in a more detailed fashion is even more revealing. For example, by the end of the first year of enrollment a staggering $35 \%$ of all academic dropouts among black students had occurred. Of those who dropped out for nonacademic reasons, $27 \%$ left school by the end of year one. By the end of the sophomore year, $70 \%$ (238) of academic dropouts and 53\% (168) of nonacademic dropouts had occurred among black students.

Hispanic students had patterns of academic progress similar to those for black students. Seventy-eight percent of Hispanic academic dropouts and $68 \%$ of nonacademic dropouts occurred by the end of the sophomore year. Of the students who graduated, $26 \%$ did so 1 year or more beyond 4 years. Asian and white student longitudinal academic patterns were comparable. The attrition rates after 2 years for academic versus nonacademic reasons are as follows: Asians $53 \%$ vs. $68 \%$; and whites, $66 \%$ vs. $68 \%$. In the final stages of their academic careers, $19 \%$ of whites and $20 \%$ of Asians who graduated did so after 4 years of enrollment. 


\section{MODELING BLACK STUDENT OUTCOMES IN WHITE UNIVERSITIES}

Over the past 20 years, significant changes have occurred in black student college attendance patterns in the United States. Whereas in $1964,60 \%$ of black students attended historically black institutions, by 1973 the proportion had declined to roughly $25 \%$. Until $1968,80 \%$ of all undergraduate degrees awarded to blacks were earned at black colleges or universities (Anderson, 1984). In contrast, during the 1978-79 academic year an estimated $56 \%$ of all bachelor's degrees awarded to black students were conferred by predominantly white schools (Deskins, 1983). Far too little research is available about the consequences and implications of this rapid societal change.

Previous research suggests that black students have not fared well on predominately white college campuses. Relative to white students, they have lower persistence rates, lower academic achievement levels, less likelihood of enrollment in advanced degree programs, poorer overall psychosocial adjustment, and lower postgraduation occupational attainments and earnings (Blackwell, 1987; Thomas, 1981).

Recent findings show black students' attrition rates to be five to eight times higher than those for white students on the same campuses. Past research characterizes the "fit" between black students and white colleges as a poor one (Allen, 1987). Accompanying these realities is the paradox of black students on white campuses who are academically successful. Little research has been done to compare successful and unsuccessful black college students. For that matter, few studies have examined differences between black students (Fleming, 1984; Allen, 1985). "Within-race" comparisons offer fertile possibilities for increased understanding of black student outcomes on predominantly white campuses. As a supplement to "cross-race" comparisons, this approach allows for a more sensitive examination of underlying factors that differentiate black students into "successful" and "unsuccessful" groups.

For the purpose of this paper, I examine the structural, interpersonal, and psychological correlates of student outcomes in a national sample of black undergraduates drawn from six predominantly white, state-supported universities. More specifically, I address questions surrounding the accommodation between black students and white-majority universities. The major focus is on aspects of successful black student adaptation to college. Student adaptation is measured by levels of involvement in campus life, academic achievement levels, and future occupational goals. The general relevance of this research is its attempt to elaborate exchanges between individuals and the social institutions of which they are a part. The central question is: What are the dynamics of a successful accommodation between black students and the predominantly white colleges that they attend?

Prior research on black students in higher education has failed to address the multicausal, multidimensional nature of the schooling process. Instead, 
researchers have focused on student background, college environment, psychological characteristics, interpersonal relationships, and related factors without the benefit of a multivariate organizing framework. Analyses and conclusions thus have been limited to the level of simple, zero-order associations (Allen, 1985).

Tinto (1975) proposed a multivariate model for the study of student attrition. Student persistence rates were viewed as products of student interaction with college academic and social systems. The better integrated into these systems the students were, the more likely was their persistence and graduation. The multivariate model for employment in the present study investigates causal connections among five groups of variables in the Tinto model.

The first group of variables in the model pertains to student's family background (i.e., sex, father's occupation, sibling's education, mother's education, and family structure). Next are student high school experiences (i.e., percentage of blacks in high school and high school grade point average). The third set pertain to campus social interactions (i.e., campus race relations, relations with professors, and involvements with black support networks). The fourth set includes student attitudes about self, religion, race, and achievement. The final group of variables represent black student academic success-related outcomes (i.e., social involvement, academic performance, and occupational aspirations). The model presumes that black students' college adjustments, academic performances, and occupational aspirations are influenced (directly and indirectly) by these five sets of variables.

To test this model, I use data from the National Study of Black College Students, a 1981 cross-sectional study of 1,050 black undergraduate, graduate, and professional students attending the following universities: University of Michigan-Ann Arbor; University of North Carolina-Chapel Hill; University of California-Los Angeles; Memphis State University; Arizona State University; and State University of New York-Stonybrook. These schools constituted a convenience universe chosen to provide regional diversity, diversity in the proportion of black student enrollment, and ease of access. The final sample consists of 695 black undergraduates, representing a response rate of $35 \%$. Cases with missing data on any of our 21 outcome or predictor variables were excluded from this analysis; therefore, the results are based on the responses of a sample of 327 students.

The data were collected between February and June 1981 through a mail survey. Students received a questionnaire, a business reply envelope, and two follow-up letters ( 1 and 2 weeks after the questionnaires were mailed). The 15-page questionnaire required approximately one-half hour to complete. Information was gathered about students' family backgrounds, attitudes, campus experiences, aspirations, academic performance levels, and perceptions of the university context.

The empirical results are presented in three distinct phases. First, salient patterns in the distribution of individual variables are examined. Emphasis is placed on providing a full description of how students" responses to the various 
questions were distributed. Next, consideration is given to key bivariate relationships in these data, asking how important pairs of variables are related to one another. Here, Pearson product-moment correlations are calculated and tested for statistical significance. Finally, multiple regression analysis is used to examine the separate and joint effects of predictor variables on student outcomes. Three regression models are tested: Model 1 predicts social involvement; Model 2 predicts occupational aspirations; Model 3 predicts academic achievement. The models empirically elaborate interrelations between structural conditions (i.e., institutional contexts), interpersonal relationships (i.e., campus experiences), and individuals' views of reality (i.e., attitudes). In short, black student success or failure in college is seen as resulting from the simultaneous effects of student characteristics, campus relations, and attitudes. The information of primary value gained from multiple regression is, first, the proportion of total variance in outcome variables accounted for by predictor variables $\left(R^{2}\right)$ and, second, the level and direction of association between specific predictor and outcome variables $(B)$ - net of effects from other predictor variables.

Before presenting the results of the multivariate statistical analyses, it is useful to profile the sample of black college students surveyed. Sixty-five percent of our respondents were female. The sample is reasonably representative by region, year in college, and major area of study. A majority of responding students $(44 \%)$ attended universities in the South, 34\% attended school in the North, and the remaining $22 \%$ were from the West. Students were nearly equal in their distribution across the ranks of freshman (27\%), sophomore (23\%), junior $(24 \%)$, and senior (25\%). Reflecting national trends, $44 \%$ of the respondents were professional studies majors (e.g., premed, prelaw, prebusiness).

Nearly half the respondents $(45 \%)$ felt themselves to be either very little or not at all part of the general campus life. Despite these high levels of social estrangement, median grade point average for students in this sample was 2.58 (on a 4-point scale). Their median high school grade point average of 3.4 was considerably higher. This discrepancy aside for the moment, student college grade point averages do suggest reasonable academic integration (e.g., only $16 \%$ reported $\mathrm{C}$ or below grade point averages, $25 \%$ reported $\mathrm{B}$ or better averages). Respondents aspirations and achievement drive were very high; $70 \%$ planned to pursue advanced degrees beyond the bachelor's level. Many of these students expected to enter such high-prestige fields as engineering, law, medicine, or corporate business.

This sample is relatively advantaged economically, compared to the majority of black Americans. Over $70 \%$ of their parents graduated from high school; more than a quarter of the parents held college degrees. Median annual family income was $\$ 20,000$; one quarter reported incomes below $\$ 12,000$, and $14 \%$ reported incomes above $\$ 50,000$. Roughly half of these students attended high schools with over $40 \%$ black enrollment.

This profile is somewhat of a paradox. If past patterns are any indication, 
approximately half of these students will leave college for reasons other than graduation. Yet this profile describes students seemingly destined for success. They are from relatively high status homes, have superior high school records, and are highly motivated. Their extreme social estrangement from campus life provides the only exception to a largely positive pattern.

Looking at significant bivariate relationships in the data, social involvement was the highest for students who claimed better relations with faculty, higher participation in black student organization activities, and held highly positive views toward support services and race relations (Table 4). Higher socioeconomic status, northern university-based, and socially involved students had significantly higher aspirations $(r=.23, .22$, and .15 respectively). Students with better grades tended to have closer relations with faculty $(r=$ $.17)$, better high school grade point averages $(r=.22)$, and higher socioeconomic status $(r=.12)$ and to be in western universities $(r=.15)$ and be from larger high schools $(r=.16)$.

Although there was no significant sex difference in college grade point averages $(r=-.06)$, there was a significant female advantage in high school grade point averages $(r=-.23)$, indicating that black females' academic performance levels actually dropped, relative to black males', from high school to college. Students in southern universities had lower self-confidence $(r=$ $-.16)$, achievement drive $(r=-.11)$, and family socioeconomic status $(r=$ -.35 ). Interestingly, students in the South also reported more favorable campus race relations.

The predictor variables explain $20 \%, 17 \%$, and $14 \%$ of the respective variance in black student social involvement, academic achievement, and occupational aspirations. Students who are regular participants in black student organization activities (partial regression coefficient $(B=.30)$, who have positive faculty relations $(B=.13)$, who evaluate campus support services favorably $(B=.16)$, and who are male $(B=.15)$ are also more frequently involved in campus social activities. These black students report better integration in and satisfaction with the general campus social life. Academic achievement is highest for students who reported favorable faculty relations ( $B$ $=.15)$, better high school grades $(B=.24)$, and more years in college $(B=$ .12) and who attended college outside the South $(B=.15$ for West and $B=$ .12 for North) (Table 5).

Contrary to expectations, the three success-related outcome variables were not significantly intercorrelated. Occupational goals, however, were higher among students who reported great social involvement. Low achievers were as likely as high achievers to anticipate high-status positions. Unlike the white students studied by Tinto, the integration of these black students into campus social life was not a necessary precondition for academic success.

Social involvement was not significantly related to student views of campus race relations, racial composition of high school, and socioeconomic status, as expected. We must, therefore, reject the implicit "acculturation" hypothesis. There was no empirical support for the assumption that as black students' 


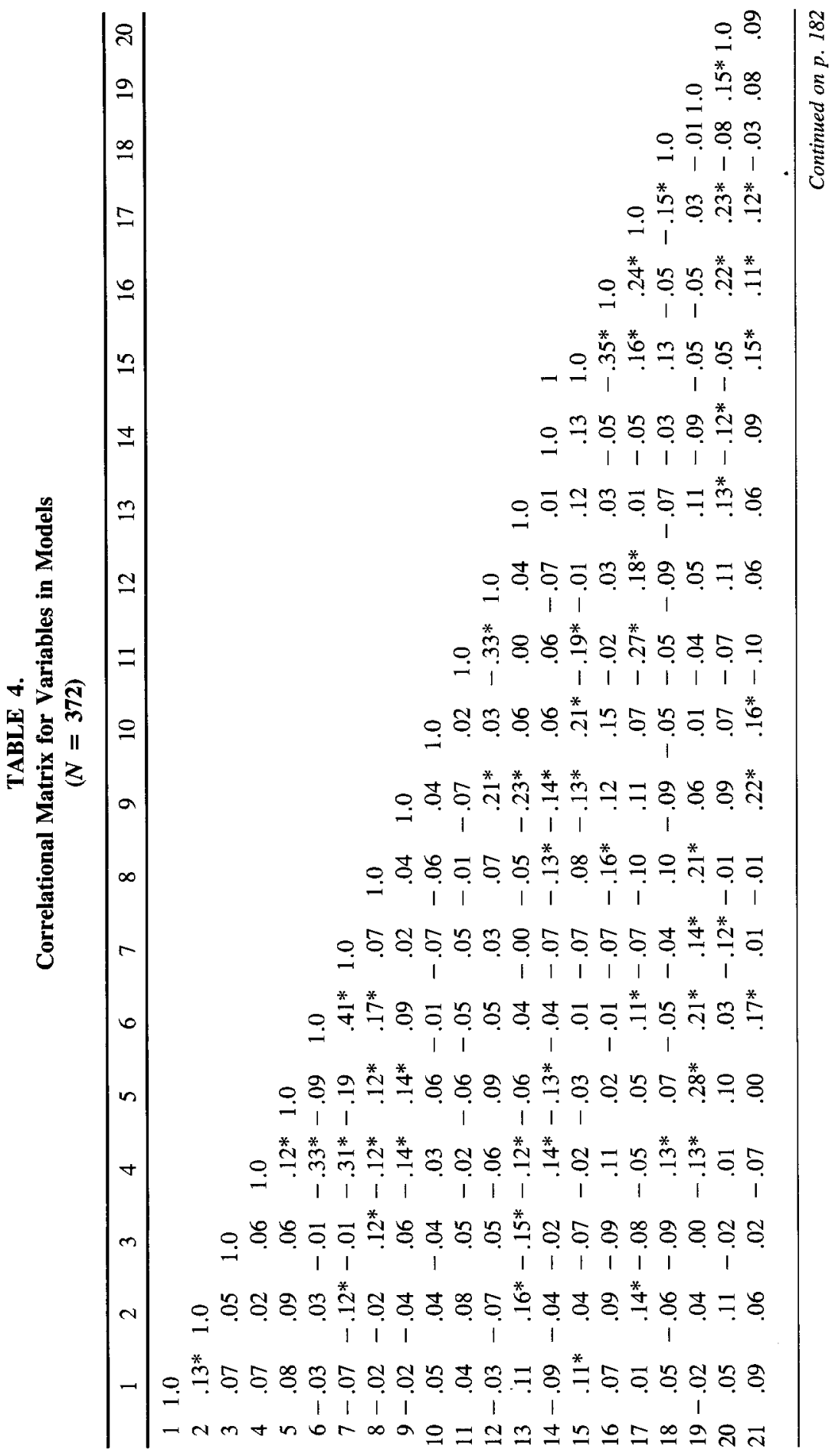




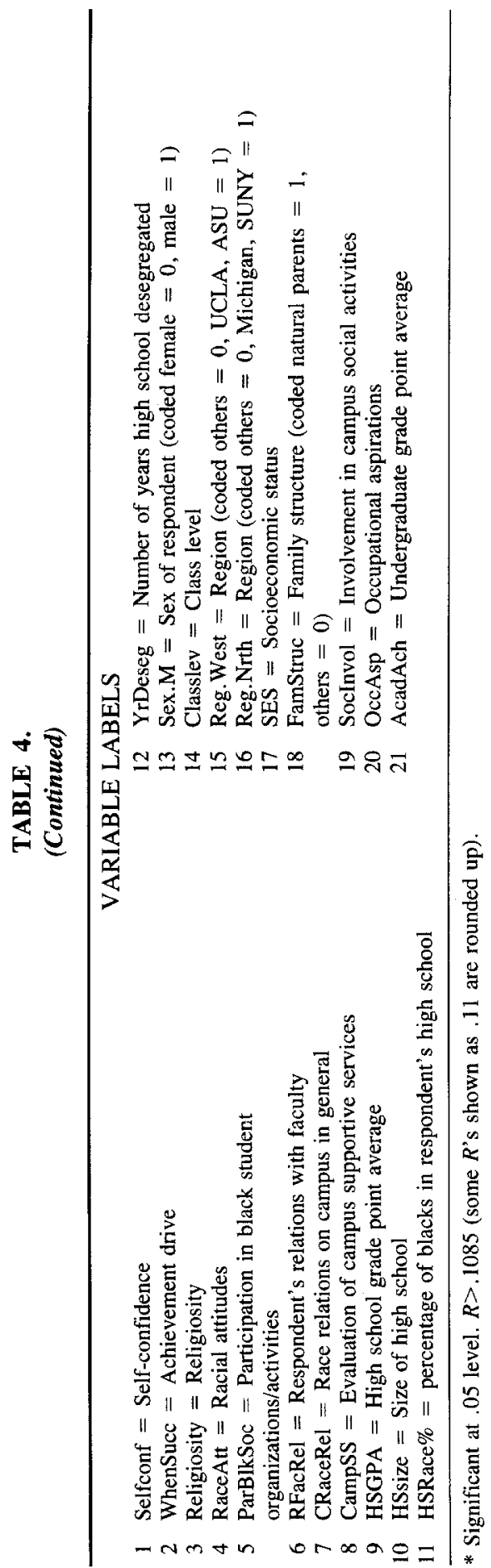


TABLE 5.

Regression Models Predicting Social Involvement, Academic Achievement, and Occupational Aspirations

\begin{tabular}{|c|c|c|c|c|c|c|c|c|c|}
\hline \multirow[b]{2}{*}{ Variables $^{a}$} & \multicolumn{3}{|c|}{ Model 1-Soc. Inv. } & \multicolumn{3}{|c|}{ Model 2-Acad. Ach. } & \multicolumn{3}{|c|}{ Model 3-Occ. Asp. } \\
\hline & $B$ & $b$ & S.E. & $B$ & $b$ & S.E. & $B$ & $b$ & S.E. \\
\hline Constant & & .887 & .623 & & $100.9^{*}$ & 39.5 & & $578.9 \dagger$ & 133.8 \\
\hline SelfConf & -.029 & -.033 & .064 & .068 & 4.9 & 4.1 & .004 & 0.8 & 13.8 \\
\hline WhenSucc & .010 & .008 & .042 & .039 & 1.9 & 2.7 & .029 & 4.7 & 9.1 \\
\hline Religiosity & -.016 & -.014 & .049 & .055 & 3.0 & 3.1 & .008 & 1.5 & 10.6 \\
\hline RaceAtt & -.045 & -.059 & .076 & -.025 & -2.1 & 4.8 & .019 & 5.3 & 16.3 \\
\hline ParkB1kSoc & .303 & $.229 \dagger$ & .041 & -.014 & -0.7 & 2.6 & .054 & 8.3 & 8.8 \\
\hline RFacRel & .133 & $.175 \dagger$ & .073 & .145 & $12.1 \uparrow$ & 4.7 & .052 & 14.5 & 16.0 \\
\hline CRaceRel & .100 & .154 & .088 & .023 & $-2.2 \dagger$ & 5.6 & -.104 & -34.8 & 18.9 \\
\hline CampsS & .156 & $.183 \dagger$ & .066 & -.017 & -1.3 & 4.2 & .016 & 4.1 & 14.2 \\
\hline HSGPA & .013 & .000 & .001 & .239 & $0.2 \dagger$ & 0.1 & .046 & 0.2 & 0.2 \\
\hline HSSize & .035 & .016 & .026 & .081 & 2.3 & 1.6 & .022 & 2.1 & 5.6 \\
\hline HSRace $\%$ & -.032 & -.015 & .027 & -.063 & -1.9 & 1.7 & .000 & 0.0 & 5.8 \\
\hline YrDeseg & -.022 & -.004 & .011 & -.011 & -0.1 & 0.7 & .004 & 1.8 & 2. \\
\hline Sex M & .149 & $.237 \dagger$ & .090 & .073 & 7.3 & 5.7 & .135 & $46.1 \dagger$ & 19.3 \\
\hline Classlev & -.002 & .001 & .037 & .118 & $4.9 *$ & 2.3 & -.098 & -13.6 & \\
\hline Reg.West & -.103 & -.198 & .109 & .150 & $18.5^{\dagger}$ & 6.9 & -.024 & 10.0 & 23. \\
\hline Reg.Nrth & -.076 & -.147 & .110 & .116 & $14.3 *$ & 7.0 & .127 & $53.1^{*}$ & 23. \\
\hline SES & .043 & .035 & .046 & -.008 & -0.4 & 2.9 & .143 & $24.9 \dagger$ & 9. \\
\hline FamStruc & .001 & .001 & .090 & -.001 & -0.1 & 5.7 & -.032 & -10.7 & 19. \\
\hline$R^{2}$ & & $.197 \dagger$ & & & $.165 \dagger$ & & & .136 & \\
\hline S.E. & & .709 & & & 45.0 & & & 152.4 & \\
\hline$N$ & & (327) & & & $(327)$ & & & (327) & \\
\hline
\end{tabular}

* Significant at the .05 level; $\uparrow$ Significant at the .01 level.

a See Table 1 for complete variable names.

$B=$ partial regression coefficient; $b=$ unstandardized regression coefficient.

cumulative experience with whites in school settings increased, their views of black-white relations would become more favorable. Nor was it demonstrated that greater exposure to middle-class (and by inference, white) culture increased their acculturation or integration into campus social networks. Black students for whom low involvement in general campus life might be expected, males and frequent participants in black student organization activities, were in fact highly involved in general campus life.

In place of the acculturation hypothesis, therefore, I suggest an "interpersonal accomplishment" hypothesis. Interpersonally accomplished black students are more involved with the general (and black student-specific) campus life. Drawing on their learned interpersonal skills, these black students manage to create and maintain favorable social relationships with blacks and whites, faculty and students, on the campus.

Students who were male and economically better off and who expressed higher achievement motivation did not have higher college grade point 
averages, as one would anticipate. However, as expected, grades were higher for students with favorable faculty relations and more years in school.

Better students, academically speaking, were on better terms with faculty. In a mutual attraction cycle, faculty interest and attention were drawn to the better-performing students. These students, in turn, viewed faculty as less threatening and sought closer interpersonal relationships with them.

There was a dramatic absence of association between occupational aspirations and predictor variables other than personal background characteristics. The absence of association between achievement and aspirations is particularly vexing. To a surprising extent, these students seem to have set their aspirations outside considerations of their demonstrated academic abilities. As students grew older, their aspiration levels declined. Aspiration levels were also lower for females and students with fewer economic resources. A strong "depressor effect" seemed to operate for each of these groups. Nevertheless, the aspirations of these black students remained high in relative terms-even in cases where grades seem not to have justified their being so. In maintaining such high aspirations, perhaps the students were adhering to the old maternal adage that encourages black children to "shoot for the moon; you may land among the stars."

To understand fully black student success on predominantly white campuses, a blending of the two perspectives must occur. Future research must look at factors internal to the person, characteristics of the institution(s), as well as overlaps between the two.

\section{DISCUSSION AND AGENDA FOR ACTION}

The extensive evidence presented here raises the specter of black miseducation (Woodson, 1969) in U.S. higher education. Black students enter college with educational disadvantages carried over from earlier years of schooling, their grades and test scores are lower, and their occupational goals are more limited than those of white students. After college entry, black students experience higher rates of discontinuance, lower levels of academic performance, greater underrepresentation in the more prestigious programs/institutions, and lower likelihood of pursuing postgraduate studies. In addition, black students report greater social and psychological distress and less satisfaction with college compared to their white peers. The profile that emerges is one that suggests a sizable and consistent black student disadvantage on the nation's college campuses.

When discussing the question of black miseducation on white university campuses, it is important to avoid reductionist thinking. For example, it would be absurd not to acknowledge the sizable numbers of black students who emerge from predominantly white colleges and universities having had very positive experiences and having received a high-quality education. Many enter these schools with excellent academic credentials and excel while enrolled, going on to achieve distinction in their chosen professions. It would also be absurd to 
dismiss the historical dimension. As a process, black miseducation in this society begins in the early years of school, resulting in a cumulative effect that is revealed in college. Black students are denied equal access to well-equipped schools and highly talented, motivated teachers throughout their elementary and high school experiences. More damaging than these educational deficits are the spiritual deficits, which deprive black students of self-confidence, motivation, and an understanding of education's transformational power. Subtle-and not so subtle-beliefs and actions in the schools and the society at large encourage views of black Americans as ultimately uneducable. Finally, one must avoid viewing black college students as mere reactors; in fact, they have the powerwithin institutionally determined limits - to shape their own destinies. On every campus, therefore, one will find black students who perform well academically despite interpersonal and institutional barriers. In such cases their success is due to talent, sheer persistence, and unwavering self-confidence.

The data presented here provide a portrait of the black disadvantage in U.S. higher education. Black students in the National Study spoke poignantly about their status as excluded individuals, socially, culturally, and academically outside the routine swirl of campus life. They report problems of social adjustment, cultural alienation, racial discrimination, and strained interpersonal relations. Of particular interest are the students' reportedly awkward relationships with their largely white faculty. Many feel that their professors are uncomfortable in the presence of black students and that they tend to avoid interactions with black students outside the classroom. Despite these problems, black students exhibit high self-concepts and high attainment aspirations.

Analyses of records of students attending the University of Michigan reveal that, on average, black students lag behind their Asian, American Indian, Hispanic, and white peers in terms of high school grades, SAT scores, and college grades. Black students also drop out at 1.5 times the rate for Asians and whites. In terms of profiles, the students separate neatly into high achievers (Asians, whites) and low achievers (blacks, American Indians, Hispanics). As might be expected, students in the low-achieving group-where still enrolledare less likely to complete their program of study, less likely to graduate on time, and less likely to make normal progress toward their degrees. Relative to their proportion of total enrollment, black students are underrepresented in fields such as the sciences or engineering.

This paper reveals aspects of the diminished quality of education received by black students in U.S. higher education. In order to understand disadvantages and to identify causes and consequences, it is vital to observe the broader context of this society. In many respects the nation's colleges and universities merely inherit and mirror a cumulative tradition. Many black students who enter college are products of urban school systems that have failed miserably in the responsibility to educate them properly. Due to financial problems, ineffective teaching, and lack of motivation, these schools consistently graduate students who are ill equipped to master the challenges of U.S. higher education.

It is important, however, that universities not be relieved of their 
responsibility for the bad state of affairs in contemporary black higher education. U.S. universities are not doing all that they can to correct the situation. One of the stated missions of public universities is to teach students using all the techniques, resources, and personnel at their disposal. The teaching mission should require that state universities adapt to the realities of serving a citizenry that is diverse in terms of cultural orientations, economic standing, and academic background. These schools are expected to design their programs and direct their activities so as to achieve the worthy goal of providing effective instruction to a representative group of students from their state and the nation.

Many universities appear to have lost sight of the basic tenets that should guide their operation. The science and art of teaching have been subordinated to the business of grantsmanship and publication among college faculty. In addition, there has arisen an ethic that views higher education as the private purview of the elite. In the extreme form these factors encourage a twisted academic Social Darwinism that continues to exclude and/or hobble individuals and groups historically relegated to the society's periphery-blacks, the poor, women, and minority group members. Faced with the smug attitude that "higher education is not for everybody" and the accompanying behaviors and norms meant to fulfill this prophecy, it is not surprising that black Americans fare so poorly in the U.S. system of higher education.

This year marks the 35 th anniversary of the Brown v. Topeka Board of Education decision and the 24th anniversary of the Higher Education Act of 1965. Both the Supreme Court's epic decision outlawing segregation in public schools and the U.S. Congress's subsequent decision to foster equal opportunity in college education helped to change the higher education experience for black Americans. The civil rights movement of the 1950s and 1960s and the black liberation movement of the $1960 \mathrm{~s}$ and $1970 \mathrm{~s}$ were also influential in redefining the college experience for black Americans. The number of black college students enrolled in higher education has more than doubled since 1960 (Thomas, 1981); and for the first time in history, black students are more likely to matriculate at predominantly white as opposed to traditionally black institutions (Deskins, 1983).

Over the long run, there has been substantial improvement in the college attainment of black Americans. On the surface, our society would seem to have made important progress toward dismantling the two-tiered "separate and unequal" higher education system based on race. Yet there are persistent problems, problems that potentially threaten or undercut black gains in higher education.

College-educated black males have higher unemployment rates than white male high school graduates; similarly, college-educated black males earn less than white male high school dropouts. There has also been a steady, precipitous decline in black college enrollment and degree attainment since 1975. So dramatic are these declines that the substantial gains in college access made by blacks during the late 1960 s and early 1970 s are in danger of complete reversal. In short, the struggle continues (Farley and Allen, 1987). 
On balance, blacks have lost ground since 1976, after dramatic increases from 1970 to 1975 . Five factors are of particular significance in explaining these declines:

1. The reduced availability of financial aid from government sources

2. Weaker enforcement of equal opportunity and affirmative action regulations

3. The redirection of university priorities from an emphasis on diversity to an emphasis on more restrictive admissions criteria

4. The higher number of black family heads who are unemployed or who are outside the labor force

5. The high number of black youngsters who fail to graduate and the high number who graduate with weak educational foundations

The following recommendations outline strategies that should be developed and actions that should be taken to improve the status of black people in U.S. higher education. For purposes of this paper, these recommendations are restricted to the role of universities and colleges. It should be noted, however that the public schools, the larger black community, black families, and the students themselves all have important roles to play in achieving the goal of expanded black participation in higher education.

Universities and colleges should

1. Develop financial aid programs that more effectively address the needs of black students and result in increased black participation in higher education.

2. Adjust the criteria on which decisions to admit black students are based, so as to give less weight to standardized test scores and more weight to other factors.

3. Institute or expand special programming focused on the needs and circumstances of black students.

4. Involve college faculty more extensively in the process of black student recruitment and retention.

5. Work to systematically change the institution's culture, self-perception, and operation. These institutions must redefine themselves as culturally plural rather than "white," in keeping with the true nature of American society.

\section{CONCLUSIONS}

In short, U.S. institutions of higher education must make genuine and sustained efforts to recruit and retain black students and to improve the quality of their educational experiences.

Twenty years ago our cities exploded, and the results of persistent deprivation, festering resentment, and frustrated dreams spilled over into a national crisis. Today most of those problems are still with us, and many have worsened. Over the years we have experienced explosions on the nation's 
campuses, as black students rose up to protest the denial of the American dream of sustained progress and upward mobility.

Unless and until the legitimate aspirations of black and other minority people are addressed, we shall all live in an uneasy quietude, nervous about when the next explosion will occur, and certain that there will be a next explosion . . . and another ... and another ... until black, brown, red, and yellow people are admitted into full citizenship, with all the rights and privileges implied.

Acknowledgments. This research was supported by funding from the Joyce Foundation and the University of Michigan, Office of Minority Affairs. An early version of the paper was delivered as the 1988 Allerton faculty conference lecture at the University of Illinois-Champaign/Urbana.

\section{REFERENCES}

Allen, Walter R. (1987). Black colleges vs. white colleges: The fork in the road for black students. Change 19(3): 28-34.

Allen, Walter R. (1986). Gender and Campus Race Differences in Black Student Academic Performance, Racial Attitudes and College Satisfaction. Atlanta: Southem Education Foundation.

Allen, Walter R. (1985). Black student, white campus: Structural, interpersonal and psychological correlates of success. Journal of Negro Education 54(2): 134-147.

Anderson, James D. (1984). The schooling and achievement of black children: Before and after Brown v. Topeka, 1900-1980. Advances in Motivation and Achievement 1: 103-122.

Blackwell, James (1987). Mainstreaming Outsiders: The Production of Black Professionals. Dix Hills, NY: General Hall.

Deskins, Donald R. (1983). Minority Recruitment Data: An Analysis of Baccalaureate Degree Production in the U.S. Totawa, NJ: Rowman \& Allanheld.

Farley, Reynolds, and Allen, Walter R. (1987). The Color Line and the Quality of Life in America. New York: Russell Sage.

Fleming, Jacqueline (1984). Blacks in College. San Francisco: Jossey-Bass.

Thomas, Gail E. (1981). Black Students in Higher Education: Conditions and Experiences in the 1970's. Westport, CT: Greenwood.

Tinto, Vincent (1975). Dropout from higher education: A theoretical synthesis of recent research. Review of Educational Research 45: 89-125.

Woodson, Carter G. (1969). The Miseducation of the Negro. New York: Associated Publishers (originally published in 1933). 